\title{
Association of interleukine-18 polymorphisms with susceptibility to prostate cancer in Iranian population
}

\author{
M. ABEDINZADEH ${ }^{1}$, M. GHODSIAN ${ }^{1, *}$, S. A. DASTGHEIB ${ }^{2, *}$, J. JAFARI-NEDOOSHAN ${ }^{3}$, M. ZARE ${ }^{3}$, N. HEIRANIZADEH ${ }^{3}$, A. RAEE-EZZABADI $^{4}$, \\ H. NEAMATZADEH ${ }^{5,6}$
}

${ }^{1}$ Department of Urology, Shahid Rahnamoun Hospital, Shahid Sadoughi University of Medical Sciences, Yazd, Iran; ${ }^{2}$ Department of Medical Genetics, School of Medicine, Shiraz University of Medical Sciences, Shiraz, Iran; ${ }^{3}$ Department of General Surgery, Shahid Sadoughi University of Medical Sciences, Yazd, Iran; ${ }^{4}$ Department of Emergency Medicine, Shahid Sadoughi University of Medical Sciences, Yazd, Iran; ${ }^{5}$ Department of Medical Genetics, Shahid Sadoughi University of Medical Sciences, Yazd, Iran; ${ }^{6}$ Mother and Newborn Health Research Center, Shahid Sadoughi University of Medical Sciences, Yazd, Iran

*Correspondence: m.ghodsian@gmail.com, dastgheibsa@gmail.com

Received June 16, 2019 / Accepted August 21, 2019

\begin{abstract}
Interleukin-18 (IL-18) is a multifunctional cytokine that augments interferon- $\gamma$ production, promotion of the Th1 immune response and acts as an important immunomediator in the development of some cancers. The current study aimed to analyze the association of the five most common polymorphisms in the IL-18 gene with prostate cancer in the Iranian population. We examined a possible association of IL-18-137G >C, $-607 \mathrm{C}>\mathrm{A},-656 \mathrm{G}>\mathrm{T},+105 \mathrm{~A}>\mathrm{C}$ and $+127 \mathrm{C}>\mathrm{T}$ polymorphisms with prostate cancer occurrence by PCR-RFLP assay. Odds ratio (OR) and 95\% confidence interval (CI) were used to assess the strength of the association between IL-18 polymorphisms and prostate cancer. Statistical analysis revealed that individuals carrying the mutant homozygote genotype of IL-18 $-607 \mathrm{C}>\mathrm{A}(\mathrm{OR}=2.251,95 \% \mathrm{CI}=1.062-4.768$, $\mathrm{p}=0.034)$ and $-137 \mathrm{G}>\mathrm{C}(\mathrm{OR}=2.364,95 \% \mathrm{CI}=1.121-4.984, \mathrm{p}=0.024)$ polymorphisms had an increased risk of prostate cancer. However, for IL-18 $-656 \mathrm{G}>\mathrm{T},+105 \mathrm{~A}>\mathrm{C}$ and $+127 \mathrm{C}>\mathrm{T}$ polymorphisms, there were no differential distributions of their genotypes between patients with prostate cancer and healthy subjects. Our results indicated that the IL-18 $-137 \mathrm{G}>\mathrm{C}$ and $-607 \mathrm{C}>\mathrm{A}$ polymorphisms were significantly associated with an increased risk of prostate cancer in the Iranian population. Thus, these polymorphisms might be used as a molecular biomarker in the early diagnosis of prostate cancer.
\end{abstract}

Key words: prostate cancer, interleukin 18, association, polymorphism, genotype

Prostate cancer is the most common non-skin cancer and the second cause of death due to malignancy in men in developed countries [1]. Since prostate cancer is most common among older men and the population is aging, prostate cancer incidence is expected to increase over the coming years. Moreover, a family history of prostate cancer and ethnicity are the only established risk factors for the disease [2]. Prostate cancer is a clinically heterogeneous disease in which genetic variants may influence the clinical outcome [3]. According to the estimates, approximately 161,360 new cases and 26,730 deaths were reported in the United States in 2017 [4]. The incidence rate of prostate cancer is approximately 9.6 per 100,000 in Iran, which considerably lower than worldwide $(32.8$ per 100,000) [5]. Prostate cancer is suggested to arise from a combination of genetic, lifestyle and environmental factors [6]. The heritability of prostate cancer susceptibility was recently estimated to $58 \%$ in a Nordic twin study, indicating that there is a strong genetic component and familial aggregation in the development of prostate cancer [7]. Thus, given the high heritability of prostate cancer, several studies have been performed to identify the inherited genetic susceptibility loci for this disease. To date, several genome-wide association studies (GWAS) have identified more than 100 common SNPs such as CYP19A1, HSD3B1, HSD17B4, CYP17A1, SRD5A2, and interleukins that were associated with the susceptibility of prostate cancer $[8,9]$.

Interleukin-18 (IL-18), originally called interferon(IFN-) $\gamma$-inducing factor, is a novel cytokine belonging to the IL-1 family and plays a strategic role in inflammation and immune reactions $[10,11]$. IL-18 is produced by a wide range of immune cells, such as monocytes, Kupffer cells, dendritic cells and activated macrophages $[12,13]$. Moreover, IL-18 belongs to proinflammatory cytokines, which, on the other hand, are capable of influencing the Th1/Th2 imbalance in Th2 direction in the suitable cytokine milieu [14]. It was recently established that IL-18 acts via a complex receptor, 
which possesses a binding chain (IL-18R $\alpha$ ) and a signaling chain (IL-18R $\beta)[15,16]$.

Human IL-18 gene is located on chromosome 11q22.2q22.3 and comprises six exons and five introns. To date, several different single nucleotide polymorphisms (SNPs) at IL-18 gene such as $-656 \mathrm{G}>\mathrm{T},-607 \mathrm{~A}>\mathrm{C},-137 \mathrm{C}>\mathrm{G},+113 \mathrm{~T}>\mathrm{G}$ and $+127 \mathrm{C}>\mathrm{T}$ have been identified, especially in the promoter region [17]. However, only $-607 \mathrm{C}>\mathrm{A}$ (rs1946518) and $-137 \mathrm{G}>\mathrm{C}$ ( $\mathrm{rs} 187238)$ polymorphisms were confirmed to affect gene expression. It is well established that the $137 \mathrm{G}>\mathrm{C}$ polymorphism changes the H4TF-1 nuclear factor binding site, while the $607 \mathrm{C}>\mathrm{A}$ polymorphism disrupts the bind of potential cAMP-responsive element binding protein [18]. IL-18 is also associated with tumorigenesis and has been reported to contribute to both anticancer and procancer processes [10]. Further, the polymorphisms in IL-18 have been found to be probably associated with the risk of prostate cancer. However, the results were inconsistent and controversial results. Thus, we have performed this study to evaluate the association of IL-18 $-656 \mathrm{G}>\mathrm{T},-607 \mathrm{C}>\mathrm{A},-137 \mathrm{G}>\mathrm{C}$, $+105 \mathrm{~A}>\mathrm{C}$ and $+127 \mathrm{C}>\mathrm{T}$ polymorphisms with susceptibility to prostate cancer in an Iranian population.

\section{Patients and methods}

Subjects. This study was approved by a local ethics committee and an informed consent was obtained from all participants included in this study. A total of 180 consecutive patients diagnosed with prostate cancer were included in this study between March 2015 and May 2018. In addition, 180 healthy matched (age and geographic origin) men with normal PSA levels $(\leq 4.0 \mathrm{ng} / \mathrm{ml})$, without a history of malignancy, and prostate complications from the general population (population based) were included.

Molecular analysis. Peripheral blood samples $(5 \mathrm{ml}$ per participant) were collected into a standard tube and stored at $-80^{\circ} \mathrm{C}$. Then genomic DNA was extracted from peripheral blood samples by a commercial QIAamp DNA Mini kit (Qiagen Co Ltd, Tehran, Iran), and stored at $-20^{\circ} \mathrm{C}$ before use. The quantity and quality of extracted DNA were estimated by a Nanodrop. In this study, the polymerase chain reactionrestriction fragment length polymorphism (PCR-RFLP) assay was used to genotype the IL-18 $-656 \mathrm{G}>\mathrm{T},-607 \mathrm{C}>\mathrm{A}$, $-137 \mathrm{G}>\mathrm{C},+105 \mathrm{~A}>\mathrm{C}$ and $+127 \mathrm{C}>\mathrm{T}$ polymorphisms. The used primers characteristics, fragments sizes, restriction enzymes and annealing temperature for each polymorphism are summarized in Table 1 . The PCR reaction was carried out in a total volume of $25 \mu \mathrm{l}$ containing $50 \mathrm{ng}$ of template DNA, $1 \mathrm{X}$ of DNA polymerase Taq buffer, $2.5 \mathrm{mM}$ of $\mathrm{MgCl}_{2}, 0.5 \mu \mathrm{l}$ of dNTP, $0.5 \mathrm{pmol} / \mu \mathrm{l}$ of each primer and $1 \mathrm{U}$ of Taq DNA polymerase. The PCR reaction conditions were as follows: initial denaturation for $5 \mathrm{~min}$ at $95^{\circ} \mathrm{C}$, then 40 cycles of 30 $\mathrm{sec}$ at $95^{\circ} \mathrm{C}$, annealing for $45 \mathrm{sec}$, extension for $60 \mathrm{sec}$ at $72^{\circ} \mathrm{C}$, followed by $6 \mathrm{~min}$ at $72^{\circ} \mathrm{C}$. Then, PCR products were digested by a restriction enzyme (Table 1 ) digestion at $37^{\circ} \mathrm{C}$ overnight. The PCR product was resolved by $3.0 \%$ agarose gel electrophoresis gel at $100 \mathrm{~V}$ for $30 \mathrm{~min}$ and visualized by UV radiation after EtBr staining.

Statistical analysis. All analysis was performed by Microsoft Excel and SPSS software (version 21.0; SPSS Inc, Chicago, Illinois). IL-18 polymorphisms allele and genotype frequencies were calculated by counting. We used the $\chi^{2}$ test to evaluate the significant departure from the HardyWeinberg equilibrium in the control group by the software package Arlequin (version 3.01). Moreover, minor allele frequencies (MAFs) in healthy subjects were estimated by a Microsoft Excel based test (Court lab). Odds ratio (OR) and $95 \%$ confidence interval (CI) were used to examine the association of IL-18 polymorphisms with prostate cancer. All tests were 2 tailed; a $p$-value of $<0.05$ was considered statistically significant.

\section{Results}

The clinical characteristics of the patients with prostate cancer and the cancer-free controls are shown in Table 2. There were no significant differences for the distributions of age, residence, family history of prostate cancer, and smoking statue between cases with prostate cancer and healthy subjects $(\mathrm{p}>0.05)$.

Table 1. Genotyping features and oligonucleotide sequences of PCR amplification primers for genotyping the IL-18 polymorphisms.

\begin{tabular}{|c|c|c|c|c|c|c|}
\hline SNP-ID & Polymorphism & Residue & Sequence Name & RE & $\mathrm{AT}\left({ }^{\circ} \mathrm{C}\right)$ & Fragments \\
\hline \multirow{2}{*}{ rs 187238} & \multirow{2}{*}{$-137 \mathrm{G}>\mathrm{C}$} & \multirow{2}{*}{ NR } & F: 5'-TTGTAACATTGTAGGAATTACC-3' & \multirow{2}{*}{ EcoRI } & \multirow{2}{*}{60} & G: 107,24 \\
\hline & & & R: 5'ATGTAATATCACTATTTTATGAGA-3' & & & C: 131 \\
\hline \multirow{2}{*}{ rs1946518 } & \multirow{2}{*}{$-607 \mathrm{C}>\mathrm{A}$} & \multirow{2}{*}{ NR } & F: 5'- СССТСТССССAAGCTTACTT-3' & \multirow{2}{*}{ MseI } & \multirow{2}{*}{54} & C: 171 \\
\hline & & & R: 5'-TTCAGTGGAACAGGAGTCCA-3' & & & A: 101,70 \\
\hline \multirow{2}{*}{ rs549908 } & \multirow{2}{*}{$+105 \mathrm{~A}>\mathrm{C}$} & \multirow{2}{*}{ Ser $>$ Ser } & F: 5'-TGTTTATTGTAGAAAACCTGG AATT-3' & \multirow{2}{*}{ Taq I } & \multirow{2}{*}{62} & A: 148 \\
\hline & & & R: 5'-CCTCTACAGTCAGAATCAGT-3' & & & C: 123,25 \\
\hline \multirow{2}{*}{ rs1946519 } & \multirow{2}{*}{$-656 \mathrm{G}>\mathrm{T}$} & \multirow{2}{*}{ NR } & F: 5'-AGGTCAGTCTTTGCTATCATTCCAGG-3' & \multirow{2}{*}{ Mwo I } & \multirow{2}{*}{60} & G: 96,24 \\
\hline & & & R: 5'-CTGCAACAGAAAGTAAGCTTGCGGAGAGG-3' & & & $\mathrm{T}: 120$ \\
\hline \multirow{2}{*}{ rs360717 } & \multirow{2}{*}{$+127 \mathrm{C}>\mathrm{T}$} & \multirow{2}{*}{ NR } & F: 5'-CCAGCTTGCTGAGCCCTTTGCTCC-3' & \multirow{2}{*}{ Eag I } & \multirow{2}{*}{63} & C: 113,21 \\
\hline & & & R: 5'-CTGTGTAGACTGCAGCAGGTGGCGGCC-3' & & & T: 134 \\
\hline
\end{tabular}

NR: Not Reported; RE: Restriction Enzyme; AT: Annealing Temperature. 
Distributions of IL-18 $-656 \mathrm{G}>\mathrm{T},-607 \mathrm{C}>\mathrm{A},-137 \mathrm{G}>\mathrm{C}$, $+105 \mathrm{~A}>\mathrm{C}$ and $+127 \mathrm{C}>\mathrm{T}$ polymorphisms in control group were found to be in Hardy Weinberg equilibrium ( $\mathrm{p}=0.762$, $0.205,0.124,0.436$, and 0.119 , respectively). Moreover, the minor allele frequencies (MAFs) of IL-18 $-656 \mathrm{G}>\mathrm{T}$, $-607 \mathrm{C}>\mathrm{A},-137 \mathrm{G}>\mathrm{C},+105 \mathrm{~A}>\mathrm{C}$ and $+127 \mathrm{C}>\mathrm{T}$ polymorphisms in the control group were $0.447,0.283,0.311,0.344$ and 0.422 , respectively.

Genotype and allele distributions of IL-18 $-656 \mathrm{G}>\mathrm{T}$, $-607 \mathrm{C}>\mathrm{A},-137 \mathrm{G}>\mathrm{C},+105 \mathrm{~A}>\mathrm{C}$ and $+127 \mathrm{C}>\mathrm{T}$ polymorphisms are shown in Table 3. For IL-18 $-656 \mathrm{G}>\mathrm{T}$ polymorphism, the TT, TG, and GG genotypes in cases with prostate cancer were $30.6 \%, 52.2 \%$ and $17.2 \%$, while in controls were $30.0 \%, 50.6 \%$ and $19.4 \%$, respectively. For IL-18 +105A>C polymorphism, the CC, CA, and AA genotypes patients with prostate cancer were $40.0 \%, 51.7 \%$ and $8.3 \%$, while in controls were $41.7 \%, 47.8 \%$ and $10.5 \%$, respectively. For IL-18 $+127 \mathrm{C}>\mathrm{T}$ polymorphism, the TT, TC, and CC genotypes in prostate cancer patients were $27.2 \%, 55.6 \%$ and $17.2 \%$, while in controls were $30.6 \%, 54.4 \%$ and $15.0 \%$, respectively. Genotype and allele distribution of the IL-18 $-656 \mathrm{G}>\mathrm{T}$, $+105 \mathrm{~A}>\mathrm{C}$ and $+127 \mathrm{C}>\mathrm{T}$ polymorphisms in prostate cancer patients and control groups were not statistically significant in comparison between patient and control group ( $>0.05$, Table 3).
Table 2. Clinicopathological characteristics of patients with prostate cancer with and controls.

\begin{tabular}{lccc}
\hline Variables & $\begin{array}{c}\text { Cases } \\
(\mathbf{n}=\mathbf{1 8 0})\end{array}$ & $\begin{array}{c}\text { Controls } \\
(\mathbf{n}=\mathbf{1 8 0})\end{array}$ & p-value \\
\hline Age (year) & $44-77$ & $42-75$ & \\
$\quad$ Range & $65.47 \pm 7.64$ & $63.24 \pm 8.35$ & 0.196 \\
$\quad$ Mean \pm SD & & & \\
Residence & $148(82.2)$ & $150(83.3)$ & 0.265 \\
$\quad$ Urban & $32(17.8)$ & $30(16.7)$ & \\
$\quad$ Rural & & & \\
Family history of prostate cancer & $4(2.2)$ & $1(0.6)$ & 0.129 \\
$\quad$ Yes & $176(97.8)$ & $179(99.4)$ & \\
$\quad$ No & & & \\
Clinical stage & $64(35.6)$ & & \\
Localized & $116(64.4)$ & & \\
$\quad$ Advanced & & & \\
PSA at diagnosis (ng/ml) & $8(4.4)$ & $156(86.7)$ & \\
$\quad<4$ & $19(10.6)$ & $21(11.7)$ & \\
$4-10$ & $153(85.0)$ & $3(1.6)$ & \\
$>10$ & $81.63 \pm 31.26$ & $5.18 \pm 2.52$ & \\
Mean \pm SD & $98(54.4)$ & $111(61.7)$ & \\
Smoking status & $82(45.6)$ & $69(38.3)$ & \\
$\quad$ Nonsmokers & & & \\
$\quad$ Smokers & & & \\
\hline
\end{tabular}

SD, Standard Deviation

Table 3. Analysis of IL-18 SNPs genotypes and alleles in prostate cancer and controls.

\begin{tabular}{|c|c|c|c|c|c|c|}
\hline \multirow{2}{*}{ SNPs } & \multirow{2}{*}{ Genotype/Allele } & \multirow{2}{*}{ Cases $(n=180)$} & \multirow{2}{*}{ Controls $(n=180)$} & \multicolumn{3}{|c|}{ Odds Ratio } \\
\hline & & & & OR & $90 \% \mathrm{CI}$ & p-value \\
\hline \multirow[t]{5}{*}{$-656 G>T$} & GG & $55(30.6)$ & $54(30.0)$ & Ref. & & \\
\hline & GT & $94(52.2)$ & $91(50.6)$ & 1.069 & $0.707-1.616$ & 0.752 \\
\hline & $\mathrm{TT}$ & $31(17.2)$ & $35(19.4)$ & 0.862 & $0.505-1.471$ & 0.589 \\
\hline & G & $204(56.7)$ & $199(55.3)$ & Ref. & & \\
\hline & $\mathrm{T}$ & $156(43.3)$ & $161(44.7)$ & 0.945 & $0.704-1.269$ & 0.707 \\
\hline \multirow[t]{5}{*}{$-607 \mathrm{C}>\mathrm{A}$} & $\mathrm{CC}$ & $74(42.8)$ & $89(49.5)$ & Ref. & & \\
\hline & $\mathrm{CA}$ & $83(46.1)$ & $80(44.4)$ & 1.070 & $0.706-1.620$ & 0.751 \\
\hline & $\mathrm{AA}$ & $23(11.1)$ & $11(6.1)$ & 2.251 & $1.062-4.768$ & 0.034 \\
\hline & $\mathrm{C}$ & $231(64.2)$ & $258(71.7)$ & Ref. & & \\
\hline & A & $129(35.8)$ & $102(28.3)$ & 1.143 & $1.031-1.935$ & 0.031 \\
\hline \multirow[t]{5}{*}{$-137 \mathrm{G}>\mathrm{C}$} & GG & $84(46.7)$ & $81(45.0)$ & Ref. & & \\
\hline & GC & $72(40.0)$ & $84(47.8)$ & 0.729 & $0.480-1.106$ & 0.137 \\
\hline & $\mathrm{CC}$ & $24(13.3)$ & $13(7.2)$ & 2.364 & $1.121-4.984$ & 0.024 \\
\hline & G & $240(66.7)$ & $246(68.3)$ & Ref. & & \\
\hline & $\mathrm{C}$ & $120(33.3)$ & $114(31.7)$ & 1.079 & $0.790-1.474$ & 0.633 \\
\hline \multirow{5}{*}{$+105 \mathrm{~A}>\mathrm{C}$} & AA & $72(40.0)$ & $75(41.7)$ & Ref. & & \\
\hline & $\mathrm{AC}$ & $93(51.7)$ & $86(47.8)$ & 1.168 & $0.773-1.767$ & 0.461 \\
\hline & $\mathrm{CC}$ & $15(8.3)$ & $19(10.5)$ & 0.770 & $0.378-1.568$ & 0.472 \\
\hline & A & $237(65.8)$ & $236(65.5)$ & Ref. & & \\
\hline & $\mathrm{C}$ & $123(34.2)$ & $124(34.4)$ & 0.988 & $0.726-1.344$ & 0.937 \\
\hline \multirow[t]{5}{*}{$+127 \mathrm{C}>\mathrm{T}$} & $\mathrm{CC}$ & $49(27.2)$ & $55(30.6)$ & Ref. & & \\
\hline & CT & $100(55.6)$ & $98(54.4)$ & 1.046 & $0.690-1.584$ & 0.832 \\
\hline & $\mathrm{TT}$ & $31(17.2)$ & $27(15.0)$ & 1.179 & $0.671-2.070$ & 0.567 \\
\hline & $\mathrm{C}$ & $198(55.0)$ & $208(57.8)$ & Ref. & & \\
\hline & $\mathrm{T}$ & $162(45.0)$ & $152(42.2)$ & 1.120 & $0.834-1.503$ & 0.452 \\
\hline
\end{tabular}

OR: Odds Ratio; CI: Confidence Interval. 
Frequency of homozygote mutant genotype for IL-18 $-607 \mathrm{C}>\mathrm{A}$ and $-137 \mathrm{G}>\mathrm{C}$ polymorphisms between prostate cancer cases and controls were significantly different $(\mathrm{p}<0.05)$. Analysis showed that individuals carrying the AA genotype of IL-18 $-607 \mathrm{C}>\mathrm{A}(\mathrm{OR}=2.251,95 \% \mathrm{CI}=1.062-$ $4.768, \mathrm{p}=0.034)$ and $\mathrm{CC}$ genotype of $-137 \mathrm{G}>\mathrm{C}(\mathrm{OR}=2.364$, 95\% $\mathrm{CI}=1.121-4.984, \mathrm{p}=0.024)$ polymorphisms had an increased risk of prostate cancer. Moreover, the occurrence of prostate cancer was increased by A allele of $-607 \mathrm{C}>\mathrm{A}$ polymorphism $(\mathrm{OR}=1.143,95 \% \mathrm{CI}=1.031-1.935, \mathrm{p}=0.031)$, but not with $\mathrm{C}$ allele of $-137 \mathrm{G}>\mathrm{C}$ polymorphism $(\mathrm{OR}=1.079$, 95\% CI=0.790-1.474, $\mathrm{p}=0.633$, Table 3 ).

\section{Discussion}

Prostate cancer is one of the major threats to men's health worldwide. Studies showed that the IL-18 can suppress antitumor immunity in a PD-1-dependent manner, PD-1 is a co-inhibitory receptor and one of the major checkpoints [19]. Thus, the polymorphisms at the IL-18 gene might be associated with the susceptibility to prostate cancer. In the current study we have evaluated the association of IL-18 $-656 \mathrm{G}>\mathrm{T},-607 \mathrm{C}>\mathrm{A},-137 \mathrm{G}>\mathrm{C},+105 \mathrm{~A}>\mathrm{C}$ and $+127 \mathrm{C}>\mathrm{T}$ polymorphisms with susceptibility to prostate cancer in the Iranian population.

To the best knowledge, this is the first study to evaluate the association of IL-18 $-656 \mathrm{G}>\mathrm{T},-607 \mathrm{C}>\mathrm{A},-137 \mathrm{G}>\mathrm{C}$, $+105 \mathrm{~A}>\mathrm{C}$ and $+127 \mathrm{C}>\mathrm{T}$ polymorphisms with the risk of prostate cancer in Iranian population. This is also the first study to investigate the association of IL-18 -656G $>\mathrm{T}$ and $+127 \mathrm{C}>\mathrm{T}$ polymorphisms with risk of prostate cancer worldwide. Our results showed that the mutant homozygote genotypes of $-607 \mathrm{C}>\mathrm{A}$ and $-137 \mathrm{G}>\mathrm{C}$ polymorphisms at the promoter region of IL-18 gene were significantly associated with an increased risk of prostate cancer in our population. To elaborate more specifically, carriers of A allele and AA genotype of IL-18 -607C $>$ A polymorphism, and carriers of CC genotype of $-137 \mathrm{G}>\mathrm{C}$ polymorphism were significantly associated with an increased risk in prostate cancer. However, our results failed to show that the IL-18 $-656 \mathrm{G}>\mathrm{T},+105 \mathrm{~A}>\mathrm{C}$ and $+127 \mathrm{C}>\mathrm{T}$ polymorphisms were significantly associated with the risk of prostate cancer in Iranian population.

To date, a few studies have been evaluated the role of the IL-18 polymorphisms in the development of prostate cancer in Indian, Chinese and Slovak populations [20-24]. In 2007, Liu et al. for the first time evaluated the association of IL-18 $-137 \mathrm{G}>\mathrm{C}$ and $-607 \mathrm{C}>\mathrm{A}$ polymorphisms with risk of prostate cancer in 265 cases and 280 controls in a Chinese population [23]. Their results showed that the IL-18 $-137 \mathrm{G}>\mathrm{C}$ polymorphism was significantly associated with an increased risk of prostate cancer in the population. In 2013, Liu et al. in a study of 375 cases with prostate cancer and 400 age-matched healthy controls examined the association of $-137 \mathrm{G}>\mathrm{C}$ and $-607 \mathrm{C}>\mathrm{A}$ polymorphisms at IL-18 gene with prostate cancer in Han Chinese [24]. Inconsistent with the previous study in the Chinese population, their results showed that none of these polymorphisms were significantly associated with an increased risk of prostate cancer. However, their results showed that individuals with wild homozygote genotype (GG) of the $-137 \mathrm{G}>\mathrm{C}$ polymorphism had a 2.165-times higher risk of prostate cancer progression than individuals with heterozygote genotype (GC) (95\% CI 1.270-3.687). Dwivedi et al. have evaluated the relationship of IL-18 (-607C $>$ A, and $-137 \mathrm{G}>\mathrm{T})$ and IL-10 $(-819 \mathrm{C}>\mathrm{T}$ and $-592 \mathrm{C}>\mathrm{A}$ ) polymorphisms with the risk of prostate cancer in an Indian population. Moreover, they have evaluated the circulating levels of IL-18 and IL-10 in the patients. Their results failed to show a significant association between $-819 \mathrm{C}>\mathrm{T}$ and $-592 \mathrm{C}>\mathrm{A}$ polymorphisms at IL-10 and an increased risk of prostate cancer. However, they have found that the IL-18 $-607 \mathrm{C}>\mathrm{A}$, and $-137 \mathrm{G}>\mathrm{T}$ polymorphisms were significantly associated with an increased risk of prostate cancer. Moreover, their results indicated that polymorphisms at promoters region of IL-18 and IL-10 genes might influence the circulating levels of these interleukins [21]. In another study, Dwivedi et al. revealed that the promoter region polymorphisms of the IL-18 gene with various modes of tobacco exposure might affect not only the susceptibility of prostate cancer risk but also the severity of this disease [22]. A recently published study by Jurecekova et al. showed that the IL-18 -607C>A polymorphism might contribute to the development of prostate cancer in a Slovak population [20]. Their study also revealed that the IL-18 $-607 \mathrm{C}>\mathrm{A}$ polymorphism was associated with the development of higher-grade carcinomas, indicating that the polymorphism may influence the prognosis and aggressiveness of prostate cancer. In 2019, Yuanyuan et al. in a meta-analysis of nine case-control studies with 1,613 prostate cancer cases and 1,630 controls found that IL-18 $-607 \mathrm{C}<\mathrm{A}$ polymorphism could decrease the risk of prostate cancer risk in the Asians, but increase the risk in the Caucasians [25]. Therefore, based on the previous studies and our results, the genotype of the IL-18 -607C>A and $-137 \mathrm{G}>\mathrm{C}$ polymorphisms could be the determinant of susceptibility to prostate cancer.

In summary, our results suggest that the IL-18 $-137 \mathrm{G}>\mathrm{C}$ and $-607 \mathrm{C}>\mathrm{A}$ polymorphisms play an important role in the development of prostate cancer in the Iranian population. Thus, these polymorphisms might be used as a molecular biomarker in the early diagnosis of prostate cancer. However, there was no significant association between IL-18 -656G $>$ T, $+105 \mathrm{~A}>\mathrm{C}$ and $+127 \mathrm{C}>\mathrm{T}$ polymorphisms and an increased risk of prostate cancer in our population. Future studies with larger sample sizes and with well-matched controls are required to assess the effect of gene-gene and gene-environment and also the same gene polymorphisms interactions, as well as more types of interleukins, should be conducted in the future.

Acknowledgements: The authors are extremely grateful to all the patients and healthy subjects who participated in the study. 


\section{References}

[1] ABEDINZADEH M, ZARE-SHEHNEH M, NEAMATZADEH H, ABEDINZADEH M, KARAMI H. Association between MTHFR C677T polymorphism and risk of prostate cancer: Evidence from 22 studies with 10,832 cases and 11,993 controls. Asian Pac J Cancer Prev 2015; 16: 45254530. https://doi.org/10.7314/apjcp.2015.16.11.4525

[2] JOHNS LE, HOULSTON RS. A systematic review and metaanalysis of familial prostate cancer risk. BJU Int. 2003; 91: 789-794. https://doi.org/10.1046/j.1464-410x.2003.04232.x

[3] FRAGA A, RIBEIRO R, COELHO A, VIZCAÍNO JR, COUTINHO H et al. Genetic polymorphisms in key hypoxia-regulated downstream molecules and phenotypic correlation in prostate cancer. BMC Urol 2017; 17: 12. https://doi. org/10.1186/s12894-017-0201-y

[4] LI R, QIN Z, TANG J, HAN P, XING Q et al. Association between 8q24 Gene Polymorphisms and the Risk of Prostate Cancer: A Systematic Review and Meta-Analysis. J Cancer 2017; 8: 3198-3211. https://doi.org/10.7150/jca.20456

[5] HASHEMI M, MORADI N, ZIAEE SA, NAROUIE B, SOLTANI MH et al. Association between single nucleotide polymorphism in miR-499, miR-196a2, miR-146a and miR149 and prostate cancer risk in a sample of Iranian population. J Adv Res 2016; 7: 491-498. https://doi.org/10.1016/j. jare.2016.03.008

[6] DISCACCIATI A, WOLK A. Lifestyle and Dietary Factors in Prostate Cancer Prevention. Recent Results Cancer Res 2014; 202: 27-37. https://doi.org/10.1007/978-3-642-451959_37

[7] HJELMBORG JB, SCHEIKE T, HOLST K, SKYTTHE A, PENNEY KL et al. The Heritability of Prostate Cancer in the Nordic Twin Study of Cancer. Cancer Epidemiol Biomarkers Prev 2014; 23: 2303-2310. https://doi.org/10.1158/10559965.EPI-13-0568

[8] SISSUNG TM, PRICE DK, DEL RE M, LEY AM, GIOVANNETTI E et al. Genetic variation: effect on prostate cancer. Biochim Biophys Acta 2014; 1846: 446-456. https://doi. org/10.1016/j.bbcan.2014.08.007

[9] CHEN Y, ZHONG H, GAO J-G, TANG J-E, WANG R. A Systematic Review and Meta-Analysis of Three Gene Variants Association with Risk of Prostate Cancer: Urol J 2015; 12: 2138-2147.

[10] WANG Z, GAO ZM, HUANG HB, SUN LS, SUN AQ et al. Association of IL- 8 gene promoter $-251 \mathrm{~A} / \mathrm{T}$ and IL-18 gene promoter $-137 \mathrm{G} / \mathrm{C}$ polymorphisms with head and neck cancer risk: a comprehensive meta-analysis. Cancer Manag Res 2018; 10: 2589-2604. https://doi.org/10.2147/CMAR. S165631

[11] MOTAVAF M, SAFARI S, ALAVIAN SM. Interleukin 18 gene promoter polymorphisms and susceptibility to chronic hepatitis B infection: a review study. Hepat Mon 2014; 14: e19879. https://doi.org/10.5812/hepatmon.19879

[12] ZIMMERMANN HW, TRAUTWEIN C, TACKE F. Functional role of monocytes and macrophages for the inflammatory response in acute liver injury. Front Physiol 2012; 3: 56. https://doi.org/10.3389/fphys.2012.00056
[13] DINARELLO CA, NOVICK D, KIM S, KAPLANSKI G Interleukin-18 and IL-18 Binding Protein. Front Immunol 2013; 4: 289. https://doi.org/10.3389/fimmu.2013.00289

[14] LUND R, AITTOKALLIO T, NEVALAINEN O, LAHESMAA R, COFFMAN RL. Identification of novel genes regulated by IL-12, IL-4, or TGF-beta during the early polarization of CD4+ lymphocytes. J Immunol 2003; 171: 5328-5336. https://doi.org/10.4049/jimmunol.171.10.5328

[15] LOREY SL, HUANG YC, SHARMA V. Constitutive expression of interleukin-18 and interleukin-18 receptor mRNA in tumour derived human B-cell lines. Clin Exp Immunol 2004; 136: 456-462. https://doi.org/10.1111/j.13652249.2004.02465.x

[16] WU C, SAKORAFAS P, MILLER R, MCCARTHY D, SCESNEY $S$ et al. IL-18 receptor beta-induced changes in the presentation of IL-18 binding sites affect ligand binding and signal transduction. J Immunol 2003; 170: 5571-5577. https://doi.org/10.4049/jimmunol.170.11.5571

[17] ZHANG J, SONG T, LIANG H, LIAN J, ZHANG G et al. Interleukin-18 -137 G/C and -607 C/A polymorphisms and Alzheimer's disease risk: a meta-analysis. Neurol Sci 2016; 37: 921-927. https://doi.org/10.1007/s10072-016-2516-y

[18] ZHANG MJ, ZHOU Y, WANG X, CHEN X, PI Y et al. Interleukin-18 gene promoter 607A polymorphism, but not $137 \mathrm{C}$ polymorphism, is a protective factor for ischemic stroke in the Chinese population: A meta-analysis. Meta Gene 2016; 9: 165-172. https://doi.org/10.1016/j. mgene.2016.06.006

[19] QIAO X, XU D, SUN D, SUN S, HUANG Z et al. Association analysis of interleukin-18 gene promoter region polymorphisms and susceptibility to sporadic breast cancer in Chinese Han women. J Clin Lab Anal 2018; 32: e22591. https:// doi.org/10.1002/jcla.22591

[20] JURECEKOVA J, BABUSIKOVA E, KMETOVA SIVONOVA M, DROBKOVA H, PETRAS $M$ et al. Association between interleukin-18 variants and prostate cancer in Slovak population. Neoplasma 2017; 64: 148-155. https://doi. org/10.4149/neo_2017_119

[21] DWIVEDI S, GOEL A, KHATTRI S, MANDHANI A, SHARMA P et al. Genetic variability at promoters of IL-18 (pro-) and IL-10 (anti-) inflammatory gene affects susceptibility and their circulating serum levels: An explorative study of prostate cancer patients in North Indian populations. Cytokine 2015; 74: 117-122. https://doi.org/10.1016/j. cyto.2015.04.001

[22] DWIVEDI S, SINGH S, GOEL A, KHATTRI S, MANDHANI A et al. Pro-(IL-18) and Anti-(IL-10) Inflammatory Promoter Genetic Variants (Intrinsic Factors) with Tobacco Exposure (Extrinsic Factors) May Influence Susceptibility and Severity of Prostate Carcinoma: A Prospective Study. Asian Pac J Cancer Prev 2015; 16: 3173-3181. https://doi. org/10.7314/apjcp.2015.16.8.3173

[23] LIU Y, LIN N, HUANG L, XU Q, PANG G. Genetic Polymorphisms of the Interleukin-18 Gene and Risk of Prostate Cancer. DNA Cell Biol 2007; 26: 613-618. https://doi. org/10.1089/dna.2007.0600 
[24] LIU JM, LIU JN, WEI MT, HE YZ, ZHOU Y et al. Effect of IL-18 gene promoter polymorphisms on prostate cancer occurrence and prognosis in Han Chinese population. Genet Mol Res 2013; 12: 820-829. https://doi.org/10.4238/2013. March.15.2
[25] YUANYUAN G, XUE Y, YACHAO L, XIAO F, XU C. Association between IL-18 -607 C/A Polymorphism and the Risk of Prostate Cancer: A Meta-Analysis of Case-Control Studies. Asian Pac J Cancer Prev 2019; 20: 1595-1602. https://doi. org/10.31557/APJCP.2019.20.6.1595 